Indonesian Journal of EFL and Linguistics

Vol. 4 No. 2, 2019

eISSN: 2503-4197, pISSN: 2527-5070

www. indonesian-efl-journal.org

\title{
Teaching Practice is not Enough for EFL Teachers: Voices from IAIN Surakarta
}

\author{
Imroatus Solikhah \\ IAIN Surakarta \\ corresponding e-mail: iimqueenoslo@gmail.com \\ Teguh Budiharso \\ Mulawarman University \\ e-mail: teguhprof@gmail.com
}

\begin{abstract}
:
This study explores teaching practices for English Language Education program of IAIN Surakarta were implemented to link the gaps between theory and actual needs at schools. Relying on the qualitative approach, this study used content analysis as the main data sources, observation and interview to collect data. The results of the study show that teaching practice for the ELT in IAIN Surakarta indicate restrictions. With overall duration of 16 weeks, teaching practices at IAIN Surakarta is set in 6 credits, each of which consists of (1) micro teaching (2 credits), (2) administrative observation, (3) classroom observation, (4) classroom teaching practices. During the field practices, complaints from mentor teachers appear that practical students are not well prepared in teaching skills and limited knowledge is performed to English competence performance in the classroom. Students claim that preparation in the itinerary of teaching practice they received from campus are not definitely sufficient as too many administrative processes are emphasized and mentoring system does not suffice to equip teaching skills.
\end{abstract}

Keywords: classroom observation, mentor teachers, teaching practices 


\section{INTRODUCTION}

Teacher development is currently receiving focus of attention in the teaching preparation and profession development all over the world. Attentions have been made insides classroom and outside within which the teachers should devote their teaching careers at schools and their community (Tarman, 2012). Richards (2015) highlights that teachers' development program starts from the competences teachers should accomplish to strengthen their performance inside the classroom and those they should perform to support legitimacy in the society outside the classroom.

Programs to support the development will begin from the design of teaching practices equipped for students of teaching program in the university that offers teacher education and teacher training. The program is incurred in the teaching curriculum that induces teaching development for the training. This will take effect on the curriculum design where considerations on learning outcomes that use standardized teaching criteria should be included (Richards, 2010; Gan, 2012).

In Indonesia, the standard reference on teaching practices has been served in the PPG (Development Teacher's Profession) and PLPG (Apprenticeship for Teacher Profession Development). PPG is previously served for public teachers' status. New policy enacts that PPG is also applicable for students learning at teacher education faculty prior to their graduation taking a four year teaching program. PLPG, on the other hand, is particularly designed for the students striving to graduate from a 4 year teaching program.

Scholars (Richards, 2010; Gan, 2012; Pak, Boorer \& Chakravarthy, 2013; Budiharso, 2015) admit that in the implementation of teaching practices gaps remain exist in plethora of versions specifying the implementation of students' knowledge and real teaching practices. Knowledge on instructional design including curriculum, teaching materials, syllabus, teaching methodology and assessment is of opinion that performs different concept between what they achieve from theory in campus and at schools.

Problem on teaching competences and oral proficiency are two most predominant pitfalls English teachers should overcome. Littlewood (2007) and Carless \& Walker (2006) report that some secondary school English teachers in Asia often lack confidence in conducting communication activities in English because the teachers themselves feel that their own language proficiency is not sufficient to engage in communication or deal with students' unforeseen needs. In context of ESL teacher education, Murdoch (1994) asserts that language proficiency will always represent the bedrock of ESL teacher's professional confidence. Richards (2010) also rates that language proficiency is the most important skill among dimensions of expertise in English Language Teaching (ELT).

Teaching practice refers to all parts of training course which involve planning, teaching and evaluation of actual lessons. The activities consist of lesson 
observation and demonstration teaching (Wingard, 1974:46). As a set of activities, teaching practice deals with students as the object of teaching, student teacher and tutor who observes the students teacher when s/he is teaching in the classroom. The main objective of the program is to implement knowledge obtained from the lecturing processes in the real situation of teaching. The implementation of the knowledge consists of planning teaching materials, real teaching, writing test item, and evaluating overall materials that have been taught.

Teaching practice as a strategy inducing teaching craft for novice teacher is now widely used as the main preparation program. Problems exist however, the results of teacher competences they have been equipped in a series of teaching professions are below the expected standard. The Organization for Economic Co-operation and Development $(O E C D)$ (2015) reports that Indonesia has 32 public and 342 private teacher training institutions among 92 public universities and more than 3,000 private universities. Problems pertaining to student intake, teacher training programs, and graduate outputs prepared for teacher professions are mostly of below standard. There are not only supply imbalances relative to demand but serious deficiencies in readiness to teach effectively and help student learn.

Teacher training programs in Indonesian university preparing teacher profession have been run with minimum renewal in context of ELT. The aims of teaching practice as a compulsory course are: (1) to conduct teaching learning process to secondary students based on Prepared Lesson Plan, (2) to apply knowledge revealed from the undergraduate courses, and (3) to identify and solve problems encountered in the classroom. For this purpose, three main activities should be conducted. The activities are: (1) observation, (2) teaching (planning, applying and evaluating) at least five times, and (3) participation of weekly discussion with teaching practice supervisor (UM, 2017; UNS, 2016; Pak, Boorer \& Chakravarthy, 2013; IAIN Surakarta 2017). Teaching practice is set as a 4 to 6 credits course that each university divides its implementation in two broad categories: micro teaching and real teaching practice each of which offer 2 credits and 4 credits. Micro teaching indicates a teaching practice at campus that equips students with artificial teaching whose students are their peers. In addition, teaching practice is a real teaching at schools with their students as the real school environment (Ministry of Education, 2016).

The advance of teacher certification set in Indonesian policy has modified the format of teaching practice. Variations are made as a 4-credit teaching practice at school is modified into 1 credit observation for school administration, 1 credit observation for school classroom, and 2 credit for teaching practice. As compared to teaching practice in Brunei Darussalam, Malaysia, Philippines, and Australia, shortages present that improvement on English proficiencies that indicate students-teacher competency in English and teaching craft showing teaching procedures and mastery on required knowledge for the classroom performance are not present (Pak, Boorer 
\& Chakravarthy, 2013). English proficiency is the cornerstone and accomplishment on teaching procedures that indicates mastery of teaching techniques, curriculum, teaching materials, classroom management and teaching methodology as well as students assessment are bedrock (Pak, Boorer \& Chakravarthy, 2013; Richards, 2013).

Girard (1974) asserts the first two qualities are developed by a serious teachertraining course which aims at providing the trainee with a good mastery of the language he/she is going to teach and with the classroom techniques he/she will need in order to teach that language in any useful way. We can assume that pupils are motivated if they have the feeling of learning good authentic language, especially the spoken language, and if the teacher proves capable of giving them a good model, which he can make his pupils reproduce. The third quality depends very much on the personality of the teacher, which is the most difficult things to change.

With the above background in mind, we conducted the research for two reasons. First, teaching practices for language education program in IAIN Surakarta needs to formulate in addition to curriculum reform where PPG and PLPG are incurred as the induction program. Second, teaching practice format that would be included in the curriculum should be defined on the basis of factual needs in the campus and fields linking gaps in theoretical basis and factual requirements at schools.

As the development of orientation of ELT teacher providers, reforms have been made to guarantee the teaching programs at colleges. Teaching practice is only the beginning student-teacher would experience teaching at schools (Pak, Broorer, Chakravarthy, 2013). Development of teaching expertise embarks on teaching techniques and language proficiency (Murdoch, 1994; Richards, 2013); language contents, and teacher identity whereby rethinking of teaching practice implementations should consider much on sociocultural view of learning (Richards, 2013:10).

Reforms on teaching practice implementation would be of strong opinion as policy and curriculum reform take place (Richards, 2013; Pak, Boorer and Chakfravarthy, 2013). In this regards, IAIN Surakarta (2017) has modified changes for the reform, however, shortages are done because of the imposed top-down policy from which policy was the desk-based operations. Exclusive formats are done as only madrasahs are addressed for the teaching practice operations.

\subsection{Research Question}

The following question led our study: "How are teaching practices for English Language Education program of IAIN Surakarta implemented to link the gaps between theory and actual needs at schools?" 


\section{RESEARCH METHODOLOGY}

\subsection{Research Design}

This study used qualitative approach because it relied on narrative evidences as the primary data. The narrative evidences were obtained from curriculum documents, policy, and teaching documents. Analysis to identify the logic of policy and curriculum implementation on teaching practices was the major concern. The main data were documented in the written forms was syllabus on teaching practice, teaching materials for micro teaching, students' reports, and correspondences. The study took place in IAIN Surakarta from January to May, 2017. This study applied grounded theory (Strauss \& Corbin, 1990) to interpret the data.

\subsection{Participants}

This study involved mentor teachers, lecturers and student-teachers. This study assigned its subject in three categories: lecturers, student-teachers, and mentor teachers. The lecturers came from English language education program from IAIN Surakarta who took parts in the supervisory of teaching practices. A number of 10 lecturers, 10 mentor teachers, and 20 student-teacers were involved as research subject. The student-teachers were candidates who were performing teaching practices and mentor teachers were teacers who supervised th stundet-teachers. In addition, the 10 lecturers were those who were assigned to supervise the teaching practice during this research took place. The subjects were selected using purposive sampling that were based on the availability in the field. When this research was cunducted, 20 student-teachers from English language education of IAIN Surakarta were available for teaching practices in three schools, each consisted of 8,6 and 6 students. This way, all metor teachers and lecturers who supervised the student were selected as participants.

\subsection{Data and Sources of Data}

The sources of data of this study primarily came from curriculum records on teaching practice, documents, and testimony from the research subject. Data of this study therefore were in the forms of results on document analysis, in terms of implementation of teaching practices, curriculum design, course description on teaching practice, micro teaching design, and reports on teaching practices. To support the data, the researcher took a semi-structured interview with research subjects. The purposes of the interview is to explore needs analysis and expected format of teaching practice in reference to the academic values the research subjects deem appropriate and qualified.

\subsection{Data Collection Procedures}

Data of this study were collected in three stages. First, the researcher read thoroughly curriculum documents that displayed teaching practices. The curriculum 
was read complimentary to the regulation on the teaching practice, micro teaching, courses for teaching practice, teaching materials for teaching practices and repots on teaching practices. All documents were identified in accordance to the research questions and were administered using field notes and memos. In doing this activity, the researcher asked help from members of the research team.

In the second process, the researcher conducted a semi-structured interview to the research subjects. Interview guide was used as the basis of questions directing the objective of interview. The results of interview were recorded using field notes. Record was not used here as the complexity process to analyze the record. The interview was done first with lecturers and student-teachers at campus for practical reasons that they are available at campus. Interview with mentor teachers was conducted at schools. Prior to the interviews, the researcher made an appointment with the teachers to conform schedule they were ready to interview.

Finally, data obtained from document analysis and data from the interview were conformed and integrated in line with the research questions. The data were categorized for the analysis preparation.

Schools were selected because each had well established school culture for teaching practices. We came to each school to have observations to the teacher pactices. The participants were interviewed. Interviews were audiotaped and transcribed verbatim using qualitative techniques (Cresswell, 2009). Teachers in each school were interviewed to obtain information on the teaching practices. Classrooms for teaching practices were observed; documents, archival records and physical artifacts were collected. Follow up interviews were conducted for teachers and lecturers to verify observation and obtain information on the practices (Carpenter, 2014:684).

\subsection{Data Analysis Techniques}

To analyze the data, the researcher adapted a study by Brezicha, Bergmark, and Mitra (2014) to using the grounded theory to interpret the data (Strauss \& Corbin, 1990). The analysis consisted of two steps: a line by-line analysis and coded of the recorder and transcribed data of observation and interview to identify major inductive themes. An inductive coding scheme was used to analyze the data. In this case, the inductive coding process consisted of questions posed to ourselves relating teaching practice implementation, how the initiative was introduced, the practice of maintaining teaching programs, and factors affecting the implementation of teaching practices (Brezicha, Bergmark, and Mitra, 2014:105)

Then we and member of research team read individually the observation and interview transcripts to find patterns in the data. After analyzing the empirical data, all researcher discussed the tentative inductive themes, resulting in a shared undrestanding portrayed in emergent themes. Comparing our individual themes, we combined our ideas through a process of data reduction (Miles and Huberman, 1994) to focus on the following categories: phylosophy and purposes of the reform, teacher 
practices, and context influencing the school culture. In the second round of the analysis process, we developed guiding questions based on the categories of data. The questions are: "What is the phylosophy and vision of the teaching practice?, What occurs in the implementation of teaching practice? And What affect the run of teaching practice?". Moving back and forth between the data from this study and literaure on teaching practice and teacher's sensemaking led to the creation of case descriptions (Brezicha, Bergmark, and Mitra, 2014:106).

Operationally, data of this study were analyzed using two models of analysis. Process of data analysis refers to interactive process analysis from Miles and Hubermen (1994). This process involves: data reduction, data display, verification and conclusion drawing. To identify the focus of research, the researcher focused its analysis into theme analysis.

In the reduction stage, all data both documentary and interview results were confirmed. The data were selected to find the relevant facts on the aspects of teaching practices that were contributable to the teaching practice curriculum and data of teaching practice contents relevant to the curriculum were administered. Data were categorized as in their classification. Data that are not relevant will be sorted out.

In the display stage, all relevant data were described in a unit of analysis. It may take a table or a figure that delineates linkages of aspects of curriculum, contents of curriculum, and structure of curriculum. Logic and reasoning of the description might be added complementary to the display.

Verification and conclusion drawing were applied to crosscheck the substance of each part in the display to achieve credible data. This verification was done in line with data trustworthiness procedures so that definite conclusion was figured as the final conclusion stating that the data fixed and matched to the research questions and the objectives of this study.

Themes of this study were identified in two steps: aspects the teaching practices should cover as the standard contents and targets the teaching practices should be applied. The first themes were used to devise curriculum objectives and curriculum contents. The second theme dealt with the structure of teaching practice curriculum to be included in the teaching practice areas in the curriculum. The structure included number of credits, scope of teaching materials, sequence, and the linkages with other courses in the fields of teaching areas, e.g. TEFL, materials development, language assessment, and micro teaching. The data were analyzed by using the model of interactive analysis from Miles and Hubermen (1994).

\section{FINDINGS}

\subsection{Implementation of Teaching Practice in IAIN Surakarta}


Teaching practice for the ELT program in IAIN Surakarta has been implemented on factual basis, formal stipulation and empirical basis derived from actual practices at school. Our document analyses, observations and results of interviews to studentteachers, mentor teachers at schools, lecturers and head of English department are summarized in the sections that follow, delineating general background that accentuate the teaching practice curriculum and its implementations in IAIN Surakarta.

Teaching practice for ELT program in IAIN Surakarta is packaged into 6-credits and implemented in a variety of ways. Table 1 shows the provisions of credit allotment of the package.

Table 1. Credit allotment of teaching practuce package.

\begin{tabular}{|c|l|l|l|}
\hline No & Name of course & Credit & Duration \\
\hline 1 & Micro teaching-Semester $5^{\text {th }}$ & 2 & 2 weeks \\
\hline 2 & $\begin{array}{l}\text { Magang I (apprenticeship) school } \\
\text { administration observation }\end{array}$ & 1 & 1 week \\
\hline 3 & Magang II—classroom observation & 1 & 1 week \\
\hline 4 & Magang III—classroom teaching practices & 2 & 12 weeks \\
\hline & & 6 & 16 weeks \\
\hline
\end{tabular}

As table 1 suggest, teaching practice for ELT program in IAIN Surakarta comprises of 6 units, weighting for 6 credits.

\subsubsection{Micro Teaching}

Micro teaching course is set in the undergraduate of ELT curriculum for 2 credits delivered in one semester. One semester program is imperatively conducted in 16 weeks which one meeting in each week. The duration of teaching is 50 minute $\mathrm{x} 2=$ 100 minutes.

In practice, results of observation, document analysis and testimony from studentteachers, and lecturers of micro teaching show evidences that micro teaching is served in two weeks, with a half after day classroom meetings. The classroom meeting is available in every 2 days, supervised by one mentor lecturer, covering 30 students in each class. In a running semester, teaching practice course accepts 250 students, admits 30 to 35 students in each class, and 1 mentor lecturer for one class. With 250 students, micro teaching course invites 8 mentor lecturers to train. Diversity of teaching plans and performance appears from one mentor to another as results of no defined teaching outline and standard of performance and teaching materials for the micro teaching course.

Implementation of micro teaching course is deemed to do in trivialities and indicated that some lecturers performed unprofessional conducts, leaving the class during 
teaching, letting students to practice the teaching on their own, and leaving responsibility for the readiness and completeness of the course. Substantially, students complain that no introductory materials are served as the foundation to understand what micro teaching is and what ultimate goals are going to achieve as the learning outcomes.

The interviewed students admit that teaching practice course is served in 12 days with 30 students in one class. One student should perform twice during the whole project. In every performance one student should prepare one Lesson Plan and Teaching materials. Problems that exist include lesson plan and teaching materials are not well prepared as no supervision adequate to improve and develop as students should work on their own mastery.

\subsubsection{Magang I and Magang II}

Magang or apprenticeship is set for the student-teachers to achieve actual experience. Magang $I$ is for the observation of school administration practices and magang II is for the classroom teaching observation, each magang is done within 6 days. The output of the Magang is a report written by students for the supervisors.

Testimony from student-teachers, supervisor lecturers, and mentor teachers shows evidences that limitations appear resulting complaints from school community. The purposes of observation on school administration promote problems as follows:

1. Office activities are interfered by the presence of students

2. Time to supervise does not conform

3. Level of understanding of each students on administration diverse

4. Some school administrations are complicated and it is difficult to share

5. Certain school administrations are secret

Pertaining to teaching classroom observations, most classroom teachers do not welcome because the class is annoyed and extra time should be served for the students during the class activities. Some, however, attest that classroom observation releases no problems as long as the student-teacher is aware of classroom ethics and rules. In all, classroom observation should be done with full attention and prior formal notification to the principals.

Conversely, student-teachers executing magang confirm that they are novice and no background information has been received prior to the school attendance. Supervision from campus dictated by the committee as guidance during observation is not enough. Students are of thinking ways they have to apply to collect data of school administration and classroom observations. They are occupied in the eyes that perfect instruments for observations must be developed through validation procedures. One supervisor confirms misconceptually that instruments for observation is subject to prepare.

\subsection{Classroom Teaching Practices}


Classroom teaching practice is the ultimate goal of overall teaching package. Implementation of teaching practice engages variety of evidences showing diverse drawbacks and shortages.

Drawn from complaints of some mentor teachers, we contend that real teaching practice should receive priority attention. Interview results and document analysis show evidences that three factors need attention. First, student knowledge and craft in teaching techniques is not sufficient for the real practice in the classroom. Second, linkage between curriculum practice at schools and theories at campus mostly lays on verbal information, without prior confirmation to the school practices. Corrolarly, student knowledge in curriculum practices mismatched with the actual needs at schools. Third, content knowledge in teaching materials the students perform is of beyond standard, making alignment to pursue teaching materials, classroom management and the whole classroom interactions dropped. Fourth, language proficiency that is used to interact in the classroom using English as medium of instruction is poor.

Readiness of real teaching practice at school that is begun from the micro teaching course contributes major problems. Failure in serving the micro teaching with sufficient teaching crafts profoundly depletes student performance in classroom teaching practice thereby detrimental teaching practices are complained. Complaints on micro teaching state that:

It is the harmful class. My lecturer left the class before finished time. Students are let to trajectory on their own, in uncertainty. (Source 1).

I think the lecturer is not responsible to his job. We are asked to teach on our own experiences. We don't know what to teach, how to develop learning objective, and what teaching techniques are suitable. (Source 2).

Of the major complaints, management to teach micro teaching receives the most protests. Micro teaching is done in 12 meetings, delivered in every 2 days. In class has 30 students, in average 5 students perform in one meeting. Students did not receive guidance how to write lesson plan, teaching materials, teaching performance, and assessing students. Majority students affirm that entry point the students received during micro teaching contributed significant constraints when students come to real teaching practices at schools.

As mentor teachers normally claimed, problems on real teaching practices also deplete the acceptance of student-teachers and student-teachers lack of identity. One of the mentor teachers insisted:

It is disappointed. The student has not enough preparation for teaching. The teaching techniques are limited, language proficiency is below standard, and his confidence is problematic. (Source 1). 
I think it is a complex problem. I suspect that the unit in campus to prepare student competence in teaching is not well prepared. It should start from micro teaching that is of limitation, teaching courses that are not well developed. What make strange, how come students bring knowledge of curriculum that is completely different from the practices at schools. (Source 2).

Teaching practice plan that assign student to perform five times teaching before examination allegedly rise problems for mentor teachers. At the strong response, mentor teachers strongly argue that it is not enough for certain students to allow for examination after five performances. However, letting students stay longer at school for just trial of teaching will make the teaching process not conducive. In exception, a very few students perform better than in general, however, this remains to indicate that teaching practices in IAIN Surakarta require immense improvements. Micro teaching as the milestone program should be entirely updated. In addition, teaching courses are the bedrocks prior to the real teaching practices preparing students with recent theories and trends in teaching.

In contact that teaching practices are problematic but doable, guarantee of the quality management is initiated to serve. Our findings show that supervisory by lecturers and mentor teachers are prominent. Limitations appear because students do not have enough preparation to perform adequately. Written materials are ready but served in restrictions. Frequency of teaching performance in the classroom has not yet provided guarantee of good teaching.

Regarding curriculum contents of teaching practice, evidences show the following:

- Materials in micro teaching mismatch to teaching practice needs in terms of lesson plan format, teaching materials, and assessment

- Instructional design that include core competence, indicators, and basic competences are differently perceived by lecturer and mentor teacher

- Syllabus design for one semester program is not supplied in campus but required for teaching plans at school

- Material development for lesson plan is not devised

- Assessment forms are not designed

Students claimed they found very difficult to select teaching method appropriate to the teaching materials. References obtained from micro teaching and classroom observation do not suffice. When teaching has been running, students also found constraints to anticipate naughty students who make troubles during the class. They claimed that experience in micro teaching does not give exposure to anticipate trouble makers in the classroom.

Students also confirm that five teaching trials are not enough to give exposure before examination. Besides, supervision to develop written teaching tools, such as lesson plan, teaching materials, assessment, media and other resources is not satisfactorily 
provided both by mentor teachers or lecturers. Most lecturers leave classroom when students are performing teaching practice. Surprisingly, not all mentor teachers are happy to receive students for consultation as time for teaching is tied and the attendance of student teachers does not waive teacher jobs.

The sites of teaching practice also come as prominent evidence that make the teaching practices are not well perceived. All sites are madrasah, Islamic schools operated by Ministry of Religious Affair. This evokes that teaching practices developed by IAIN Surakarta is allegedly designed for Islamic schools, even though the status of graduates is an ELT teacher.

\section{DISCUSSION}

Our study has found evidences that teaching practice for ELT program at IAIN Surakarta are done in restrictions. Renewal has been applied but it invokes the topdown policy. We frame the evidences in context of academic substance to resolve problems of curriculum reform and policy.

We draw from the study by Renandya et. al (2013) that teaching practice recently becomes the ultimate program to prepare ELT teachers. In addition, Pak, Boorer and Chakravarthy (2013) admit that reform in teaching practice has been made to anticipate teaching needs in the global era suggesting renewal on teaching method, teaching materials and changes on teacher attitudes.

This study shows that reform in teaching practice in IAIN Surakarta has been made in trivialities. Teaching course that consist of 6 credits has been set into micro teaching, magang I, magang II, and magang III. The goals of each course provide diverse perception for student-teachers as a result of no standard dimension of course design. Micro teaching is set in 2-credit course, but the implementation is short, as only 2 week sessions are provided. The micro teaching is handled by 8 lecturers whose teaching orientation and target are different. Corrolarly, students receive different teaching materials and concepts of real teaching and it makes students get trouble when they conduct real teaching practices at schools. Complaints are made that students did not receive perfect concepts on curriculum reform, lesson plan, teaching materials, and teaching assessment.

Viewed from Pak, et. al (2013), we assure that policy on teaching practice provided by IAIN Surakarta produce contentious implementation. Reform should start from facts and evidences to include in the needs assessment. Perceptions from candidates, mentor teachers and some lecturers are of dissention in practices (Tarman \& Chigisheva, 2017). Pak et.al (2013) reports that teaching practice in Brunei Darusslam has been designed since 1956 up to now. Renewal was firstly developed from identifying teaching concept using TEACH Model, teaching format, assessment model, and teaching practice categories into units or credit hours. Following the reform, trials in several schools are made sustainably from year to 
year. Reflected in IAIN Surakarta, renewal of teaching practice for ELT program should be redesigned using a model that the institution considers to match its vision.

In addition, sequence of teaching course that include micro teaching, observation for school administration, observation for classroom teaching, and actual teaching practices is the milestones. Micro teaching performs the bedrock and real teaching practice at schools is the cornerstone. Murdoch (1994) advocates that teaching crafts is the first expertise students should accomplish. Richards (2012), Renandya, et.al (2013), and Pennington and Richards (2016) admit that teaching practice should provide students with language proficiency, teaching craft and student identity.

Language proficiency entails competency a teacher should perform in the classroom when he/she teaches and English is used as a medium of instruction. Restriction in language proficiency will make teacher not confident to teach (Murdoch, 1994), teaching paces are not running well (Richards, 2013; Tarman \& Chigisheva, 2017), and student underestimate (Girard, 1974). Perceived in a wider context, language proficiency is associated with speaking competences, and other aspects of oral English as a teacher in the classroom should perform as a model, mechanic, and physician (Williams, 1997). Our findings show that teaching practice for ELT program in IAIN Surakarta has limitation to set student-teachers improve their language proficiency. Teaching practice is more perceived to perform teaching materials set previously at homes, and taught in a certain class using the native language. This way, teaching practice is more the implementation of teaching in front of the class. In the eyes of teaching course contents, teaching practice has been identified a series of courses that are not necessarily having a close linkage each other in terms of tied contents and sequences (Murdoch, 1994; Tarman \& Dev, 2018).

Complaints of mentor teachers claiming low proficiency of some student-teachers as perceived from the knowledge and mastery of teaching techniques and language contents, our study accuses evidences that some students are of opinion, with exception, very few perform better (Tarman \& Gürel, 2017). We draw from the study by Renandya, et.al (2013) that Asian teachers, specifically Indonesian English teachers are of low confidence to use English as the medium of instruction. The reason is simply they lack competence in oral English (Murdoch, 1994), teaching English using English as a medium of instruction is hard to do (Renandya, et. al, 2013), and the language proficiency especially in oral English of the teachers are low (Richards, 2013).

Site of teaching practice is of vital to discuss in this section. All student-teachers having teaching practice are sent to madrasah, Islamic senior schools the institution may coordinate. This may evoke that ELT program in IAIN has been designed specifically for English for Islamic Purposes. As ELT graduates from IAIN receive equal status from other teacher colleges in Indonesia and event in international levels, this finding presents negative impression. Lecturers attest that the choice of 
Imroatus Solikhah and Teguh Budiharso

madrasah is of the policy of the institution where everybody should adhere. Negative perception may not have been considered previously except problems of distribution of student-teachers at schools should be overcome through the coordination between institution and schools.

\section{CONCLUSION}

The present study was aimed to explore implementation of the teaching practice and curriculum reform in the teaching courses at IAIN Surakarta. The findings of the study aspires the conclusion below. In general, teaching practice for the ELT program in IAIN Surakarta has been well-implemented, stipulated on empirical basis considering much actual practices at schools. Teaching practice is packaged into 6credits, outlined into 2-credit micro teaching, 1-credit for school administration, 1credit for classroom observation, and 2-credits for real classroom teaching practice. The success story of the revewal is associated with curriculum reform invoking new regulation, statutory, and policy in each level of courses, e.g. micro teaching, Magang I, Magang II, and Magang III. The problems remain unsolved include: micro teaching is the backbone of teaching practice but the implementation impairs real teaching practice as a whole. Micro teaching should serve the very entry level behavior of actual teaching but standard teaching materials integral to teaching at school mismatched. Magang I and Magang II to observe school administration and classroom teaching are almost useless and time consuming as both jobs are doable integral to the teaching practice in Magang III. On the foremost ground, teaching practice that is intended to equip students with real teaching at schools receives minimum attention in terms of procedures, regulation, supervision, readiness on curriculum, and teaching strategies. Utmost problems pertaining to language profieciency, teaching craft, teacher competences, curriculum development, and instructional design remain below par.

\section{REFERENCES}

Budiharso, Teguh. (2015). Teaching Practice: Does It Substantiate Teachers Profession?, Lingua, 13(2): 132-148.

Brezicha, K., Bergmark, U., \& Mitra, D. (2014). One Size Does Not Fit All: Differentiating Leadership to Support Teachers in School Reform. Educational Administration Quarterly 51.96-132

Carless, D., \& Walker, E. (2006). Effective Team Teaching between Locak and Native-Speaking English Teachers. Language and Education 20(6).

Gan, Zhengdong. (2012). Understanding L2 Speaking Problems: Implication for ESL Curriculum Development in a Teacher Training Institution in Hong Kong. Australian Journal of Teacher Education, 37(1): 43-59.

Girard, Dennis. (1974). Motivation: The Responsibility of the Teacher. London, ELT Journal, January, 1974. 
Littlewood, W. (2007). Communicative and Task-Based Language Teaching in East Asian Classrooms. Language Teaching 40(3).

Miles, M. B., \& Huberman, A. M. (1994). Qualitative Data Analysis: An Expanded Sourcebook. Thousand Oaks, CA: Sage Publications.

Murdoch, G. (1994). Language Development Provision in Teacher Training Curricula. ELT Journal, 48(3): 253-259.

Pak, Yong Leong, Boorer, David, \& Chakravarthy, Gitu. (2013). Development of the Practicum Component of Teacher Education in Brunei Darusslam. Brunei Darussalam: Universiti Brunei Darusslam.

Pennington M \& Richards, JC. (2016). Teacher identity in language teaching: integrating personal, contextual, and professional factors. RELC Journal, 47(1): 5-24.

Renandya, A. Willy; Lee, Wai Lim; Wah, Kai Leong \& Jacobs, M. George. (2013). A Survey of English Language Teaching Trends and Practices in Southeast Asia. Singapore: RELC SEAMEO.

Richards, C. Jack, Gallo, B. Patrick, \& Renandya A. Willy. (2015). Exploring Teacher's Beliefs and the Process of Change. Singapore: RELC SEAMEO.

Richards, J. (2010). Competence and Performance in Language Teaching. RELC Journal, 41(2): 101-122.

Richards, CJ. (2013). Second Language Teacher Education Today. Singapore: SEAMEO Regional Language Centre.

Strauss, A.L., \& Corbin, J. M. (1990). Basics of Qualitative Research: Grounded Theory Procedures and Techniques. Newbury Park, Calif: Sage Publications.

Tarman, B., \& Dev, S. (2018). Editorial: Learning Transformation through Innovation and Sustainability in Educational Practices. Research in Social Sciences and Technology, 3(1)

Tarman, B., \& Chigisheva, O. (2017). Transformation of educational policy, theory and practice in post-soviet social studies education. Journal of Social Studies Education Research, 8(2), I-IV. 10.17499/jsser.93128

Tarman, B., \& Gürel, D. (2017). Awareness of social studies teacher candidates on refugees in Turkey. Journal of Social Studies Research, 41(3), 183-193. 10.1016/j.jssr.2016.11.001

Tarman, B. (2012). Prospective Teachers' Beliefs and Perceptions about Teaching as a Profession, Educational Sciences: Theory \& Practice - 12(3), 1-24.

The Organisation for Economic Co-operation and Development (OECD)/Asian Development Bank. (2015). Education in Indonesia: Rising to the Challenges. Paris: OECD Publishing. http://dx.doi.org/10.1787/97892642.30750-en.

Universitas Negeri Malang. (2017). Petunjuk Pelaksanaan PPL Keguruan Universitas Negeri Malang. Malang: Universitas Negeri Malang.

Williams, M. \& Burden, R. L. (1997). Psyhology for Language Teacher: a Social Constructivist Approach. Cambridge University Press: Cambridge. 
Imroatus Solikhah and Teguh Budiharso

Wingard, Peter. (1974). Teaching Practice. English Language Teaching Journal. 29(1): 23-36. 